University of Nebraska - Lincoln

DigitalCommons@University of Nebraska - Lincoln

\title{
Climate trends of the North American prairie pothole region 1906-2000
}

Bruce Millett

W. Carter Johnson

Glenn Guntenspergen

Follow this and additional works at: https://digitalcommons.unl.edu/usgsstaffpub

Part of the Geology Commons, Oceanography and Atmospheric Sciences and Meteorology Commons, Other Earth Sciences Commons, and the Other Environmental Sciences Commons

This Article is brought to you for free and open access by the US Geological Survey at DigitalCommons@University of Nebraska - Lincoln. It has been accepted for inclusion in USGS Staff -- Published Research by an authorized administrator of DigitalCommons@University of Nebraska - Lincoln. 


\title{
Climate trends of the North American prairie pothole region 1906-2000
}

\author{
Bruce Millett • W. Carter Johnson • \\ Glenn Guntenspergen
}

Received: 27 June 2006 / Accepted: 20 October 2008 / Published online: 16 February 2009

(C) Springer Science + Business Media B.V. 2009

U.S. government works are not subject to copyright.

\begin{abstract}
The Prairie Pothole Region (PPR) is unique to North America. Its millions of wetlands and abundant ecosystem goods and services are highly sensitive to wide variations of temperature and precipitation in time and space characteristic of a strongly continental climate. Precipitation and temperature gradients across the PPR are orthogonal to each other. Precipitation nearly triples from west to east from approximately $300 \mathrm{~mm} /$ year to $900 \mathrm{~mm} /$ year, while mean annual temperature ranges from approximately $1{ }^{\circ} \mathrm{C}$ in the north to nearly $10^{\circ} \mathrm{C}$ in the south. Twentieth-century weather records for 18 PPR weather stations representing 6 ecoregions revealed several trends. The climate generally has been getting warmer and wetter and the diurnal temperature range has decreased. Minimum daily temperatures warmed by $1.0^{\circ} \mathrm{C}$, while maximum daily temperatures cooled by $0.15^{\circ} \mathrm{C}$. Minimum temperature warmed more in winter than in summer, while maximum temperature cooled in summer and warmed in winter. Average annual precipitation increased by $49 \mathrm{~mm}$ or 9\%. Palmer Drought Severity Index (PDSI) trends reflected increasing moisture availability for most weather stations; however, several stations in the western Canadian Prairies recorded effectively drier conditions. The east-west moisture gradient steepened during the twentieth century with stations in the west becoming drier and stations in the east becoming wetter. If the moisture gradient continues to steepen,
\end{abstract}

B. Millett $(\bowtie)$

Department of Geography, South Dakota State University,

Box 504, Brookings, SD 57007, USA

e-mail: bruce.millett@sdstate.edu

W. C. Johnson

Department of Horticulture, Forestry, Landscape, and Parks, South Dakota State University, Brookings, SD 57007, USA

G. Guntenspergen

U. S. Geological Survey, Patuxent Wildlife Research Center, Laurel, MD 20708, USA 
the area of productive wetland ecosystems will shrink. Consequences for wetlands would be especially severe if the future climate does not provide supplemental moisture to offset higher evaporative demand.

\section{Introduction}

Weather records for North America show a general trend of increasing temperature and precipitation during the twentieth century (Gullett and Skinner 1992; Karl et al. 1993; Nkemdirim and Weber 1999; National Assessment Synthesis Team 2001; IPCC 2007; Sauchyn et al. 2003). However, these trends are not uniform across the continent. Significant regional differences exist and complicate efforts to generalize the response of specific natural ecosystems to altered climate.

Our analysis focused on the Prairie Pothole Region (PPR), which includes 58 million glacially formed wetlands that are highly sensitive to climate variability (Poiani and Johnson 1991; Larson 1995; Sorenson et al. 1998; Johnson et al. 2005). This paper provides an overview of recent climatic trends across the PPR. Most relevant published information is for the larger Great Plains region (Borchert 1950; Bryson and Hare 1974; Woodhouse and Overpeck 1998). We use daily precipitation and daily maximum and minimum temperature data from January 1906 to December 2000 to characterize historic temporal and spatial climate patterns for the PPR and the implications of these patterns for the future of wetland biodiversity.

The PPR occupies approximately $750,000 \mathrm{~km}^{2}$ in the center of the continent in both the United States and Canada (Fig. 1) (van der Valk 1989; Millett 2004). It is bounded on the south by the limits of the Laurentide ice sheet of the Wisconsinan glaciation and on the west by the Missouri River in the United States that occupied an ice marginal position during full glacial times and by the Rocky Mountain foothills in Canada. The northern limit of the PPR is the southern boundary of the Canadian boreal forests of Alberta, Saskatchewan, and Manitoba (Bird 1961), and the eastern limit is the prairie-deciduous forest transition zone (Buell and Facey 1960).

The climate of the PPR and of the larger northern Great Plains region is influenced by three air masses: Continental Polar, Maritime Tropical, and Maritime Polar (Bryson and Hare 1974). The complex interactions among these air masses in the middle of a large continent create one of the most extreme and dynamic climates on Earth (Winter 1989; Ahrens 2007; Woodhouse and Overpeck 1998). Temperatures can exceed $40^{\circ} \mathrm{C}$ in summer and drop below $-40^{\circ} \mathrm{C}$ in winter. High summer temperatures and low humidity cause high evapotranspiration rates that can quickly dry shallow wetlands. The PPR has a strong precipitation gradient, with areas to the north and west receiving less precipitation than locations to the south and east. Evaporation exceeds precipitation by $60 \mathrm{~cm}$ in southwestern Saskatchewan and in eastern Montana but only by $10 \mathrm{~cm}$ in Iowa (Winter 1989).

The PPR also exhibits considerable spatial and temporal variability in rainfall (Johnson et al. 2004). The 1930s drought was particularly notable, comprising at least four distinct drought episodes: 1930-1931, 1934, 1936, and 1939-1940 (Riebsame et al. 1991). During severe droughts, most wetlands go dry during the summer and may remain dry for multiple years. In wet periods, wetlands and lakes can expand to the point of overflowing and may form surface connections between otherwise geographically isolated wetland depressions (Tiner 2003; Shapley et al. 2005). 


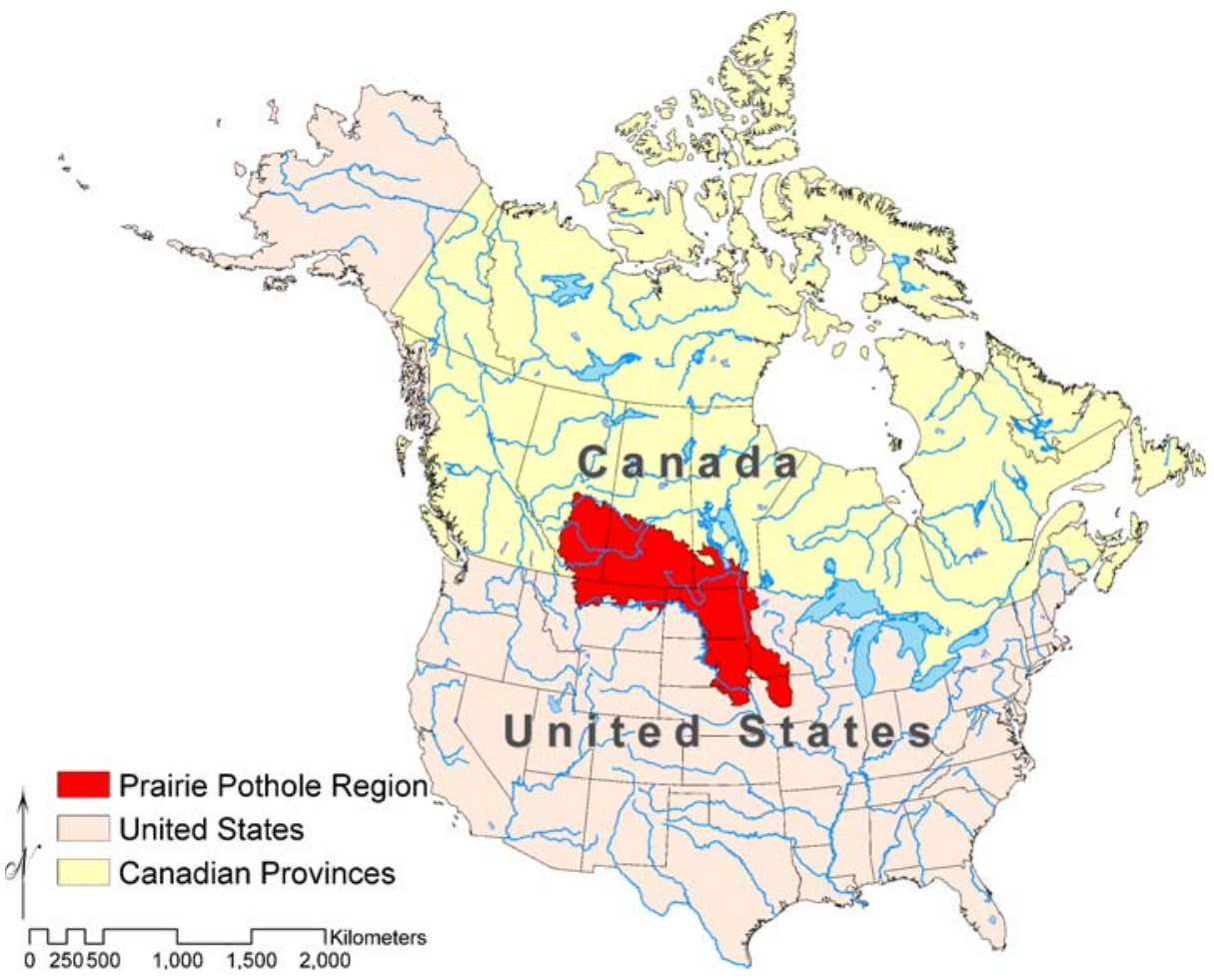

Fig. 1 Map of the Prairie Pothole Region (PPR) of North America based on ecoregion classification (Omernik 1987, 1995)

However, wetlands may be connected by groundwater even during droughts (Winter and LaBaugh 2003).

The Holocene climate of central North America has varied markedly (Wells 1970). Temperatures during the Hypsithermal (4,000-8,000 years B.P.) in the northern Central Plains were $1^{\circ} \mathrm{C}$ to $2^{\circ} \mathrm{C}$ (Bartlein et al. 1984,1998 ) or $2^{\circ} \mathrm{C}$ to $3^{\circ} \mathrm{C}$ (Denton and Porter 1970) warmer than today. Bluemle et al. (1999) characterized this period as ten or more "little ice ages" separated by global warming events. Records during this period showed evidence of aridity, increased salinity, and higher than present temperatures, with grasslands spreading farther north (Lemmen et al. 1997). The prairie-forest border along the eastern margin of the PPR has moved in response to climate fluctuations, moving west during cool, wet periods and east during warm, dry periods (Anderson 1983; Clark et al. 2001).

Climate controls the many important ecosystem services provided by prairie wetlands. For example, climate largely determines the amount of water that enters, resides in, or leaves a wetland basin. Prairie wetlands stabilize local watershed budgets by buffering the effects of drought and inundation. Some wetlands provide focused groundwater recharge during wet periods, which may stabilize surface water levels during dry periods. During wet periods, they store large amounts of surface water reducing flooding in streams and rivers. Prairie wetlands also are habitat for 
thousands of plant and animal species. The PPR is an important breeding ground for North American waterfowl (Batt et al. 1989).

Research has indicated that prairie wetlands and their biodiversity would be vulnerable to climate change. Larson (1995) used statistical modeling to project that a combined $3{ }^{\circ} \mathrm{C}$ temperature increase and a $10 \%$ decrease in precipitation would reduce the number of wet basins by $74 \%, 31 \%$ and $56 \%$ for Canada Parkland, Canada Grassland and United States Grassland subdivisions, respectively. Another statistical analysis estimated that climatic warming could reduce the number of breeding ducks settling in the PPR by half (Sorenson et al. 1998). Johnson et al. (2005) used a climate-driven, wetland simulation model to show that a warmer future climate would shift optimal breeding conditions for waterfowl eastward in the PPR, toward where most wetlands have been drained, and away from areas of high wetland density and favorable nesting cover that produced most ducks during the twentieth century.

\section{Data and methods}

\subsection{Weather stations and records}

Ecoregions represent areas with similar biotic and abiotic phenomena (Wiken 1986; Omernik 1987, 1995; USEPA 1996) and were the strata from which weather stations were selected for this analysis. Three weather stations were selected from each of six modified Level III ecoregions (Fig. 2). These 18 stations were chosen based on their longevity and completeness of record and geographic location within each ecoregion. Within ecoregions weather stations were mostly selected from locations to represent the greatest environmental range. A different set of weather stations (340 stations with 30 year records) was used to create a map of historic temperature and precipitation across the PPR.

Data for U.S. weather stations were obtained from the National Climate Data Center (NCDC), while Canadian weather data were purchased from the Environment Canada (EC) Manitoba and Arctic Regional Office. There were 588 weather stations within the PPR, and of these, approximately 130 stations had collected some data prior to 1932. All stations had breaks in their period of record. For example, only partial weather data were collected at some stations in some years. At other stations data were collected only in certain seasons or collection was interrupted for several months or years. Each of the 18 climate data sets that we compiled had three variables: daily precipitation, maximum daily temperature, and minimum daily temperature. Climate data sets were either truncated or expanded to 95 years to be of equal length. The total number of records for each of these three variables was 34,699 for each station. Fewer Canadian weather stations were used than U.S. stations because there were fewer ecoregions in Canada.

Many techniques have been used to reconstruct missing weather data (Kemp et al. 1983; Karl and Williams 1987; Mott et al. 1994; DeGaetano et al. 1995; Eischeid et al. 2000). Eischeid et al. (2000) compared six different methods of spatial interpolation and found no systematic bias in any of the estimation procedures particularly where the terrain and the density of surrounding stations were relatively uniform. We reconstructed missing daily air temperature and precipitation data by averaging data 


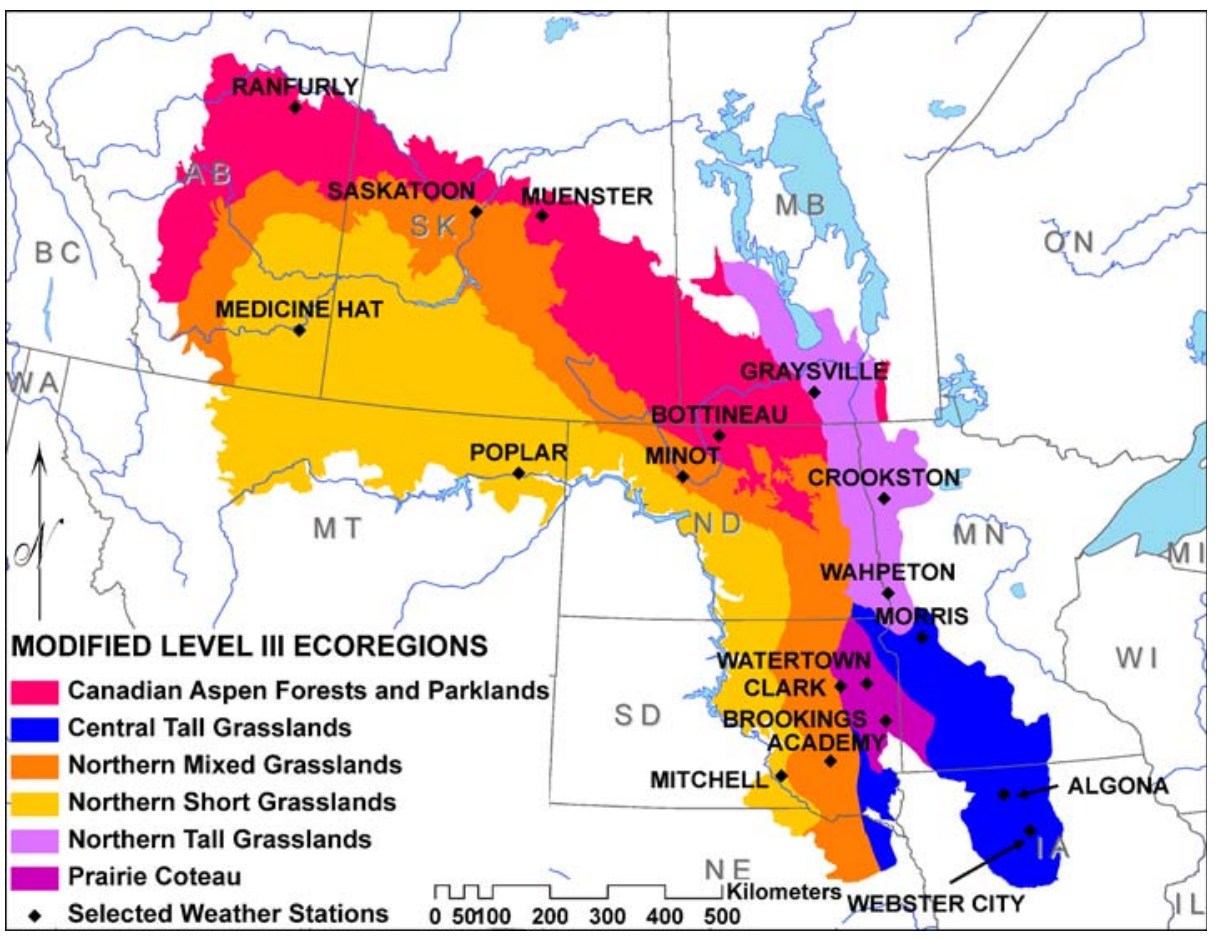

Fig. 2 Map of the modified Level III ecoregions based on USEPA (1996). The weather stations selected for analysis are shown

from two or three neighboring stations, usually within $40 \mathrm{~km}(25 \mathrm{mi})$. For the few stations where only one nearby station was available for reconstruction, the single best estimator method (Eischeid et al. 2000) was used. Because topographic relief of the PPR is gradual, differences in elevation between target station and neighboring stations were nearly always less than $100 \mathrm{~m}$.

\subsection{Missing data accuracy assessment}

Data from target and neighboring stations were compared to determine the reliability of the reconstruction method. Spearman rank correlations were calculated for paired daily precipitation data while Pearson correlation coefficients were calculated for maximum and minimum daily temperature data. Spearman rank correlations are more appropriate than Pearson correlations when normal distributions cannot be assumed, as is the case for daily precipitation (Clark and Hay 2004). Seven of the eighteen target stations were randomly chosen, and from these, 5 months with no missing data were randomly chosen, thus producing 35 months of data. Correlation coefficients were computed between target and neighboring stations for corresponding months.

The majority of weather stations were missing fewer than $2 \%$ (694 days) of the total records for each weather element (Table 1). Two stations required extensive supplemental data. Graysville, MB was missing data for 13,095 days (37.7\%). The 
Table 1 Number and percentage of missing daily precipitation and maximum and minimum temperature records for selected weather stations in the Prairie Pothole Region of North America for 1906 to 2000

\begin{tabular}{|c|c|c|c|c|c|c|}
\hline \multirow[t]{3}{*}{ Station } & \multicolumn{2}{|c|}{ Daily precipitation } & \multirow{2}{*}{\multicolumn{2}{|c|}{$\begin{array}{l}\text { Daily maximum } \\
\text { temperature }\end{array}$}} & \multirow{2}{*}{\multicolumn{2}{|c|}{$\begin{array}{l}\text { Daily minimum } \\
\text { temperature }\end{array}$}} \\
\hline & \multirow[t]{2}{*}{$\overline{\text { Days }}$} & \multirow[t]{2}{*}{ Percent } & & & & \\
\hline & & & Days & Percent & Days & Percent \\
\hline Academy, SD & 206 & 0.6 & 464 & 1.3 & 494 & 1.4 \\
\hline Algona, IA & 624 & 1.8 & 575 & 1.7 & 670 & 1.9 \\
\hline Bottineau, ND & 94 & 0.3 & 234 & 0.7 & 195 & 0.6 \\
\hline Brookings, SD & 84 & 0.2 & 192 & 0.6 & 186 & 0.5 \\
\hline Clark, SD & 890 & 2.6 & 948 & 2.7 & 1,008 & 2.9 \\
\hline Crookston, $\mathrm{MN}$ & 184 & 0.5 & 209 & 0.6 & 219 & 0.6 \\
\hline Graysville, MB & 13,373 & 38.5 & 12,956 & 37.3 & 12,957 & 37.3 \\
\hline Medicine Hat, AB & 129 & 0.4 & 173 & 0.5 & 163 & 0.5 \\
\hline Minot, ND & 218 & 0.6 & 251 & 0.7 & 291 & 0.8 \\
\hline Mitchell, SD & 419 & 1.2 & 436 & 1.3 & 463 & 1.3 \\
\hline Morris, $\mathrm{MN}$ & 233 & 0.7 & 325 & 0.9 & 330 & 1.0 \\
\hline Muenster, SK & 5,417 & 15.6 & 1,278 & 3.7 & 1,223 & 3.5 \\
\hline Poplar, MT & 4,726 & 13.6 & 4,697 & 13.5 & 4,702 & 13.6 \\
\hline Ranfurly, AB & 38 & 0.1 & 46 & 0.1 & 50 & 0.1 \\
\hline Saskatoon, SK & 13 & 0.0 & 16 & 0.0 & 89 & 0.3 \\
\hline Wahpeton, ND & 1,937 & 5.6 & 2,066 & 6.0 & 1,977 & 5.7 \\
\hline Watertown, SD & 11,404 & 32.9 & 11,410 & 32.9 & 11,405 & 32.9 \\
\hline Webster City, IA & 386 & 1.1 & 370 & 1.1 & 319 & 0.9 \\
\hline
\end{tabular}

two longest periods of missing data were from January 1, 1906 to August 1, 1925 (7,152 days) and from November 1, 1988 to December 31, 2000 (4,444 days). Watertown, SD was missing approximately 11,406 days (32.9\%). The longest data gap occurred between January 1, 1906 and December 31, 1931 (9,496 days). A shorter gap occurred between January 1, 1996 and December 31, 2000 (1,827 days). Although these two stations required extensive reconstruction, they provided the most complete weather records and the needed geographic distribution within each ecoregion.

Median Spearman's rank correlations between observed and estimated precipitation were higher for southern stations (Academy, SD; Clark, SD; Morris, $\mathrm{MN}$; and Watertown, SD) than for northern stations (Bottineau, ND; Graysville, $\mathrm{MB}$; and Muenster, SK). Of the 35 year/month combinations tested at the seven weather stations, 25 had moderate to strong correlation coefficients $(r=0.40$ to $0.90)$ and 10 year/month combinations had very weak to low correlations coefficients $(r<0.40)$. Precipitation was underestimated for Academy, SD; Clark, SD; and Muenster, SK and overestimated for Bottineau, ND; Graysville, MN; Morris, MN; and Watertown, SD (Table 2).

Proximity and number of stations used to estimate missing data influenced the strength of correlation coefficients. Use of three nearby stations matched observed data at target weather stations better than did those of one or two nearby stations. Correlation coefficients between observed data at target and neighboring stations were weaker for northern than for southern stations probably because northern stations were farther apart. Correlations generally were higher for temperature than for precipitation. There were 32 months with strong to very strong correlation 
Table 2 Spearman's correlation coefficients between target and neighboring weather stations calculated to assess accuracy of reconstructing missing daily precipitation data
Correlation coefficients reported are of the five randomly selected months for each randomly selected PPR weather station

\begin{tabular}{|c|c|c|c|c|}
\hline Station & Date & Number & $r$ value & $p$ value \\
\hline \multirow[t]{5}{*}{ Academy, SD } & 1908 FEB & 28 & 0.7087 & 0.0000 \\
\hline & 1922DEC & 31 & 0.4808 & 0.0089 \\
\hline & 1940JUN & 30 & 0.5293 & 0.0036 \\
\hline & 1954AUG & 31 & 0.7144 & 0.0000 \\
\hline & 1975MAR & 31 & 0.8242 & 0.0000 \\
\hline \multirow[t]{5}{*}{ Bottineau, ND } & 1913APR & 30 & 0.5836 & 0.0011 \\
\hline & 1930JUL & 31 & 0.3028 & 0.1103 \\
\hline & 1962MAR & 31 & 0.5821 & 0.0011 \\
\hline & 1979MAY & 31 & 0.6674 & 0.0001 \\
\hline & 1998NOV & 30 & 0.8863 & 0.0000 \\
\hline \multirow[t]{5}{*}{ Clark, SD } & 1912AUG & 31 & 0.8505 & 0.0000 \\
\hline & 1924DEC & 31 & 0.2153 & 0.2515 \\
\hline & 1946MAR & 31 & 0.7053 & 0.0000 \\
\hline & 1971APR & 30 & 0.7857 & 0.0000 \\
\hline & 1991JUN & 30 & 0.6906 & 0.0000 \\
\hline \multirow[t]{5}{*}{ Graysville, MB } & 1909AUG & 31 & 0.4189 & 0.0219 \\
\hline & 1943APR & 30 & 0.1599 & 0.3955 \\
\hline & 1959SEP & 30 & 0.456 & 0.0120 \\
\hline & 1984DEC & 31 & 0.2728 & 0.1442 \\
\hline & 1999JUL & 31 & 0.1162 & 0.5388 \\
\hline \multirow[t]{5}{*}{ Muenster, SK } & 1909MAY & 31 & 0.2668 & 0.1531 \\
\hline & 1920JAN & 31 & 0.1726 & 0.3595 \\
\hline & 1953JUN & 30 & 0.3901 & 0.0337 \\
\hline & 1965SEP & 30 & 0.5577 & 0.0016 \\
\hline & 1988MAR & 31 & 0.5314 & 0.0029 \\
\hline \multirow[t]{5}{*}{ Morris, MN } & 1919JUL & 31 & 0.8291 & 0.0000 \\
\hline & 1937MAY & 31 & 0.5123 & 0.0042 \\
\hline & 1951JUN & 30 & 0.2906 & 0.1190 \\
\hline & 1980NOV & 30 & 0.6137 & 0.0004 \\
\hline & 2000DEC & 31 & 0.647 & 0.0002 \\
\hline \multirow[t]{5}{*}{ Watertown, SD } & 1932FEB & 28 & 0.2707 & 0.1548 \\
\hline & 1950AUG & 31 & 0.4055 & 0.0298 \\
\hline & 1968APR & 30 & 0.6063 & 0.0006 \\
\hline & 1987MAY & 31 & 0.515 & 0.0047 \\
\hline & 1992DEC & 31 & 0.4174 & 0.0250 \\
\hline
\end{tabular}

coefficients $(r>0.70)$ for maximum daily temperature and 3 months with weak to moderate correlation coefficients ( $r=0.20$ to 0.70 ) (Table 3 ). Minimum daily temperature patterns were similar; there were 33 months with strong or very strong correlations and 2 months with moderate correlations (Table 4). Because our method of estimating missing data was satisfactory for the large majority of months and stations we used this approach to complete the data files and to conduct our climate trend analyses.

\subsection{Daily weather data trend analysis}

Simple linear regression was used to determine trends in total annual precipitation and mean annual temperature data over the period of record. Annual temperature and precipitation data for each station were smoothed at 3-year periods to reduce 
Table 3 Pearson correlation coefficients between target and neighboring stations calculated to assess accuracy of reconstructing missing daily maximum temperature data

Correlation coefficients reported are of the five randomly selected months for each randomly selected PPR weather station

\begin{tabular}{|c|c|c|c|c|}
\hline Station & Date & Number & $r$ value & $p$ value \\
\hline \multirow[t]{5}{*}{ Algona, SD } & $1906 \mathrm{JAN}$ & 31 & 0.8296 & 0.0000 \\
\hline & 1935MAR & 31 & 0.9750 & 0.0000 \\
\hline & $1949 \mathrm{NOV}$ & 30 & 0.9742 & 0.0000 \\
\hline & 1981MAR & 31 & 0.9229 & 0.0000 \\
\hline & 1989AUG & 31 & 0.6707 & 0.0000 \\
\hline \multirow[t]{5}{*}{ Brookings, SD } & 1912JUL & 31 & 0.9129 & 0.0000 \\
\hline & 1920JUN & 30 & 0.9420 & 0.0000 \\
\hline & $1957 \mathrm{NOV}$ & 30 & 0.9521 & 0.0000 \\
\hline & 1973JAN & 31 & 0.8770 & 0.0000 \\
\hline & 1995FEB & 28 & 0.9394 & 0.0000 \\
\hline \multirow[t]{5}{*}{ Crookston, MN } & 1909OCT & 31 & 0.9129 & 0.0000 \\
\hline & 1923JUN & 30 & 0.9420 & 0.0000 \\
\hline & 1938MAR & 31 & 0.9521 & 0.0000 \\
\hline & 1966SEP & 30 & 0.8770 & 0.0000 \\
\hline & 1987AUG & 31 & 0.9394 & 0.0000 \\
\hline \multirow[t]{5}{*}{ Medicine Hat, AB } & 1907SEP & 30 & 0.9171 & 0.0000 \\
\hline & 1924MAY & 31 & 0.7935 & 0.0000 \\
\hline & 1939SEP & 30 & 0.7154 & 0.0000 \\
\hline & $1956 \mathrm{JAN}$ & 31 & 0.8251 & 0.0000 \\
\hline & 1979MAR & 31 & 0.8294 & 0.0000 \\
\hline \multirow[t]{5}{*}{ Minot, ND } & 1920MAY & 31 & 0.8720 & 0.0000 \\
\hline & 1943MAY & 31 & 0.9283 & 0.0000 \\
\hline & 1965FEB & 28 & 0.9572 & 0.0000 \\
\hline & 1975SEP & 30 & 0.8537 & 0.0000 \\
\hline & 1991DEC & 31 & 0.9532 & 0.0000 \\
\hline \multirow[t]{5}{*}{ Poplar, MT } & 1912MAR & 31 & 0.8911 & 0.0000 \\
\hline & 1927DEC & 31 & 0.9032 & 0.0000 \\
\hline & 1939SEP & 30 & 0.8506 & 0.0000 \\
\hline & 1966APR & 30 & 0.9079 & 0.0000 \\
\hline & 1978JAN & 31 & 0.9189 & 0.0000 \\
\hline \multirow[t]{5}{*}{ Watertown, SD } & 1934MAY & 31 & 0.9589 & 0.0000 \\
\hline & 1959JUL & 31 & 0.7233 & 0.0000 \\
\hline & 1965OCT & 31 & 0.3340 & 0.0712 \\
\hline & 1976APR & 30 & 0.5345 & 0.0023 \\
\hline & $1984 \mathrm{NOV}$ & 30 & 0.7731 & 0.0000 \\
\hline
\end{tabular}

year-to-year variability and to help detect trends in magnitude and duration. Similar approaches have been used by others in cases where high temporal variability in weather data exists (Karl et al. 1995; Hansen et al. 1998; Garbrecht and Rossel 2002; NCDC 2008). Estimates from regression equations for the year 1906 were subtracted from those for the year 2000 for each weather station to show the magnitude of change and the sign (positive or negative trend) over the 95-year period. Minimum and maximum temperature data for summer (June, July, and August) and winter (December, January, and February) seasons were selected to examine long-term trends.

\subsection{Palmer drought severity index}

The Palmer Drought Severity Index (PDSI) is a widely used drought assessment measure (Alley 1984; Lohani and Loganathan 1997; Winter and Rosenberry 
Table 4 Pearson correlation coefficients between target and neighboring stations calculated to assess accuracy of reconstructing missing daily minimum temperature data

Correlation coefficients reported are of the five randomly selected months for each randomly selected PPR weather station

\begin{tabular}{|c|c|c|c|c|}
\hline Station & Date & Number & $r$ value & $p$ value \\
\hline \multirow[t]{5}{*}{ Academy, SD } & 1911JUL & 31 & 0.9482 & 0.0000 \\
\hline & 1937SEP & 30 & 0.8343 & 0.0000 \\
\hline & 1956FEB & 28 & 0.9203 & 0.0000 \\
\hline & 1973 NOV & 30 & 0.9427 & 0.0000 \\
\hline & 1989JAN & 31 & 0.7753 & 0.0000 \\
\hline \multirow[t]{5}{*}{ Brookings, SD } & 1909JAN & 31 & 0.9777 & 0.0000 \\
\hline & 1934NOV & 30 & 0.9167 & 0.0000 \\
\hline & 1944AUG & 31 & 0.9471 & 0.0000 \\
\hline & 1982MAR & 31 & 0.9557 & 0.0000 \\
\hline & 1996APR & 30 & 0.9313 & 0.0000 \\
\hline \multirow[t]{5}{*}{ Clark, SD } & 1917JUL & 31 & 0.9019 & 0.0000 \\
\hline & 1922SEP & 30 & 0.9016 & 0.0000 \\
\hline & 1954JUN & 30 & 0.9610 & 0.0000 \\
\hline & 1978DEC & 31 & 0.8455 & 0.0000 \\
\hline & 2000MAR & 31 & 0.9506 & 0.0000 \\
\hline \multirow[t]{5}{*}{ Graysville, MB } & 1926AUG & 31 & 0.6621 & 0.0001 \\
\hline & 1933ОСТ & 31 & 0.7280 & 0.0000 \\
\hline & 1956MAY & 31 & 0.9063 & 0.0000 \\
\hline & 1970JAN & 31 & 0.9232 & 0.0000 \\
\hline & 1984JUN & 30 & 0.7990 & 0.0000 \\
\hline \multirow[t]{5}{*}{ Minot, ND } & 1915JUL & 31 & 0.7974 & 0.0000 \\
\hline & 1927MAY & 31 & 0.4594 & 0.0107 \\
\hline & 1946MAR & 31 & 0.7778 & 0.0000 \\
\hline & 1963SEP & 30 & 0.8623 & 0.0000 \\
\hline & 1989DEC & 31 & 0.9707 & 0.0000 \\
\hline \multirow[t]{5}{*}{ Morris, MN } & 1909DEC & 31 & 0.9683 & 0.0000 \\
\hline & 1922OCT & 31 & 0.9280 & 0.0000 \\
\hline & 1945MAR & 31 & 0.9500 & 0.0000 \\
\hline & 1957APR & 30 & 0.9485 & 0.0000 \\
\hline & 1993AUG & 31 & 0.9229 & 0.0000 \\
\hline \multirow{5}{*}{ Wahpeton, ND } & $1918 \mathrm{NOV}$ & 30 & 0.9319 & 0.0000 \\
\hline & 1935MAR & 31 & 0.9173 & 0.0000 \\
\hline & 1957APR & 30 & 0.9797 & 0.0000 \\
\hline & 1981OCT & 31 & 0.9758 & 0.0000 \\
\hline & 1995JAN & 31 & 0.9072 & 0.0000 \\
\hline
\end{tabular}

1998; Cook et al. 1999; Nkemdirim and Weber 1999; Hayes et al. 2002). The index uses temperature, precipitation, the available water content of the soil, and Thornthwaite's method for calculating potential evapotranspiration (Thornthwaite and Mather 1957). PDSI values above +4.00 or below -4.00 represent extreme deluge and drought, respectively. PDSI values from -0.50 to +0.50 lie within the normal range. PDSI values were calculated using the PDSI program version 2.0 available from the National Agricultural Decision Support System (NADSS 2003).

The PDSI program used four input files: monthly temperature, monthly precipitation, normal monthly temperature, and the parameters. The parameters file contained the underlying soil moisture value and the negative tangent of latitude of the station. The negative tangent of latitude of the station was determined by converting the latitude for each weather station from degrees, minutes, and seconds into decimal degrees. The underlying soil moisture value was held constant across 
all weather stations. The monthly temperature input values were the average of the daily high and low for each month. The monthly precipitation values were the monthly precipitation sums for each month. The normal monthly temperatures were the long-term (95-year) average temperature for each month.

\section{Results}

\subsection{Precipitation and temperature gradients}

Precipitation and temperature gradients across the PPR were orthogonal to each other (Fig. 3) consistent with larger continental gradients. Average annual precipitation varied across the PPR from over $300 \mathrm{~mm} /$ year in the extreme northwest (Alberta) to nearly $900 \mathrm{~mm} /$ year in the extreme southeast (Iowa). For example, Poplar, MT and Crookston, $\mathrm{MN}$ are at similar latitudes $\left(48^{\circ} \mathrm{N}\right)$; however, Poplar, MT had a mean annual rainfall of $333 \mathrm{~mm}$, while Crookston, MN had a mean annual rainfall of $516 \mathrm{~mm}$. Mean annual temperature increased latitudinally from $1^{\circ} \mathrm{C}$ at the northern limit of the PPR to $10^{\circ} \mathrm{C}$ at the southern limit. To illustrate, Webster City, IA located at $42^{\circ} 28^{\prime} \mathrm{N}$ had a mean annual temperature of $8.7^{\circ} \mathrm{C}$, while Muenster, SK at latitude $52^{\circ} 11^{\prime} \mathrm{N}$ had a mean annual temperature of $0.9^{\circ} \mathrm{C}$.

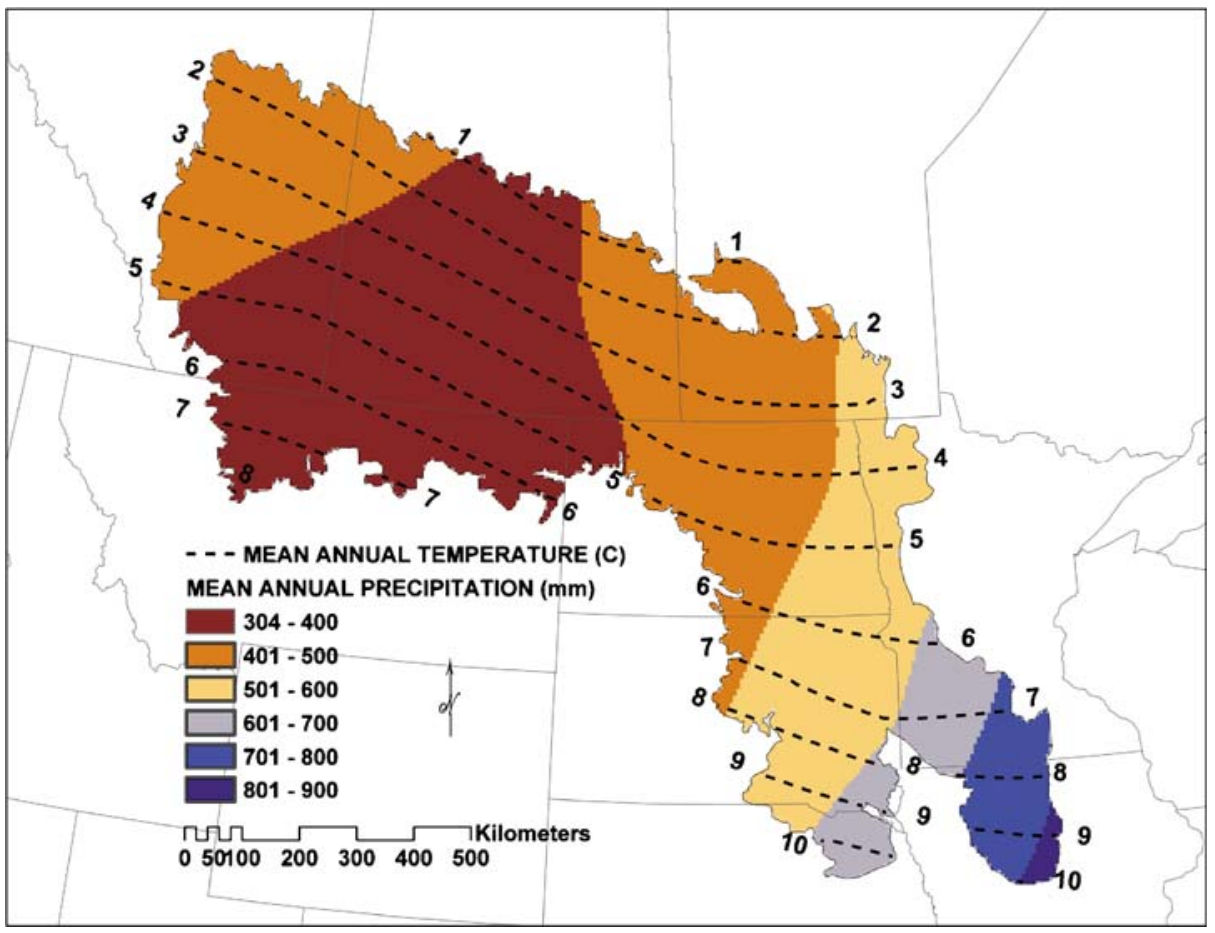

Fig. 3 Geographic patterns of mean annual precipitation and temperature for the PPR based on data from 30-year climate normals 1961-1990 for 394 weather stations 
Fig. 4 Ellipses for each ecoregion representing the $90 \%$ confidence intervals of mean annual precipitation and temperature data from 394 weather stations for the PPR

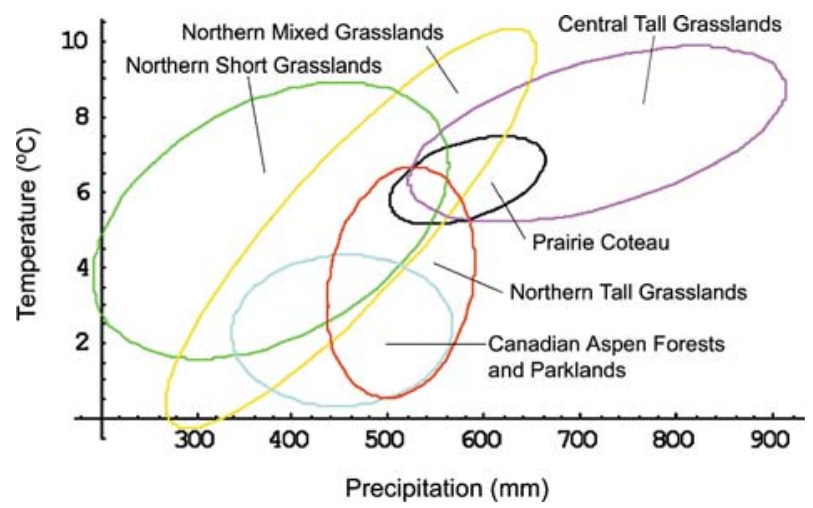

\subsection{Ecoregion climates}

Historic climate varied substantially across the ecoregions of the PPR. Ellipses were created to represent the climatic realm of each ecoregion and to portray the amount of climatic overlap among regions (Fig. 4). Precipitation in the Central Tall Grasslands exceeded that of any other ecoregion. Average temperature for the Aspen Parklands ecoregion was the coolest and did not intersect the Prairie Coteau or Central Tall Grasslands ecoregions. The area where most ellipses overlapped (approximately mean annual temperature of $5^{\circ} \mathrm{C}$ and mean annual precipitation of $530 \mathrm{~mm}$ ) is an area of highly productive and dynamic wetlands in the eastern Dakotas (Johnson et al. 2005). Generally, average temperature correlated positively with precipitation.

\subsection{Precipitation and temperature trends}

\subsubsection{Annual}

Precipitation generally increased across the PPR during the twentieth century; regression lines for ten of the eighteen weather stations had statistically significant $(p<0.05)$ positive slopes for precipitation (Table 5). The average increase in annual precipitation across all stations calculated from the regression equations was $49 \mathrm{~mm} / 95$-years or $9 \%$.

The largest increases in precipitation generally occurred along the eastern and northeastern fringe in the tall grassland ecoregions (Fig. 5), historically the wettest areas of the PPR (Fig. 4). For example, precipitation at Graysville, MB increased by $155 \mathrm{~mm}$ and by $140 \mathrm{~mm}$ at Webster City, IA. Most of the stations in the eastern half of the PPR posted significant increases in precipitation over the 95-year period, while none of the five stations did in the western half of the PPR.

Variation in long-term precipitation patterns was considerable over short distances in some sections of the PPR. For example, the two nearby Iowa stations exhibited different trends; Webster City became considerably wetter, while Algona showed no long-term trend (Fig. 5). Also, three of the five stations in eastern South Dakota showed no long-term change in precipitation, while two others showed 
Table 5 Annual precipitation trends from 1906 to 2000 for 18 weather stations based on linear regression

The (+) signifies a positive trend (wetter). Stations in bold were statistically significant $(p<0.05)$

\begin{tabular}{lll}
\hline Station & Trend & $p$ value \\
\hline Academy, SD & + & 0.0041 \\
Algona, IA & & 0.6624 \\
Bottineau, ND & + & 0.0001 \\
Brookings, SD & + & 0.0005 \\
Clark, SD & & 0.9505 \\
Crookston, MN & + & 0.0304 \\
Graysville, MB & + & 0.0001 \\
Medicine Hat, AB & + & 0.0398 \\
Minot, ND & + & 0.0001 \\
Mitchell, SD & & 0.7983 \\
Morris, MN & + & 0.0141 \\
Muenster, SK & & 0.0507 \\
Poplar, MT & & 0.1711 \\
Ranfurly, AB & & 0.1057 \\
Saskatoon, SK & & 0.1986 \\
Wahpeton, ND & + & 0.0002 \\
Watertown, SD & & 0.6875 \\
Webster City, IA & + & 0.0001 \\
\hline
\end{tabular}

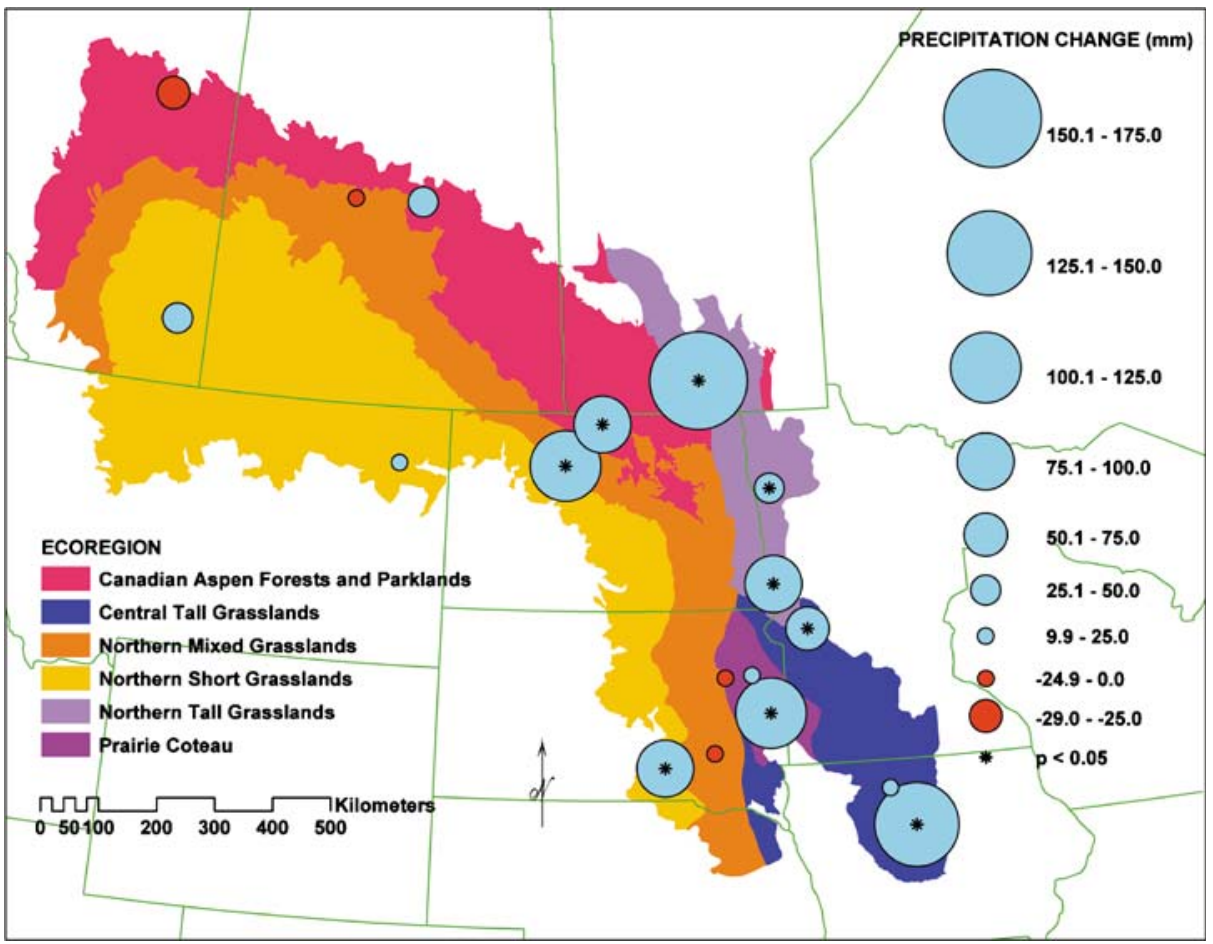

Fig. 5 Map of historic trends in annual precipitation for 18 weather stations and six ecoregions in the PPR 
significant increases. Trends among nearby stations were more consistent in the northeastern PPR but less consistent in Saskatchewan and Alberta (Fig. 5).

Long-term trends for maximum daily temperature were weaker and more variable than those for minimum temperature. Based on linear regression analysis the average maximum daily temperature across weather stations was $11.72^{\circ} \mathrm{C}$ in 1906 and $11.58^{\circ} \mathrm{C}$ in 2000 , a statistically non-significant decrease of $0.14^{\circ} \mathrm{C}(p=0.5006)$. Twelve stations had negative slopes for maximum daily temperature; seven of these were statistically significant $(p<0.05)$ (Table 6$)$. Three of the six stations with positive slopes for maximum temperature were statistically significant $(p<0.05)$.

Trends towards cooler maximum temperatures were concentrated in the southeastern portion of the PPR, historically the warmest stations (Fig. 6). Trends in the central and western portions of the PPR were more variable but included the only stations with significant warming. Based on linear regression analysis, the magnitude of change in temperature ranged from near $0^{\circ} \mathrm{C}$ to approximately $2^{\circ} \mathrm{C}$ (Fig. 6).

Minimum daily temperature (Fig. 7) changed more uniformly across the PPR than did maximum daily temperature. Average daily minimum temperature regressed across stations in 1906 was $-1.54^{\circ} \mathrm{C}$ and $-0.54^{\circ} \mathrm{C}$ in 2000 , a significant increase of $1^{\circ} \mathrm{C}$ $(p=0.0049)$. Ten of 13 stations showed statistically significantly $(p<0.05)$ increases in minimum temperature, while two stations had significant negative slopes (Table 6).

Stations trending toward warmer minimum temperatures were widespread (Fig. 7); however, the greatest magnitude of increase occurred in central and western portions of the PPR. The largest increases of nearly $3.5^{\circ} \mathrm{C}$ occurred in western portions of the Canadian Aspen Forests and Parklands ecoregion (Fig. 7). The few

Table 6 Annual mean maximum (TMAX) and minimum (TMIN) temperature linear regression trends from 1906 to 2000 for 18 weather stations

\begin{tabular}{llllll}
\hline Station & $\begin{array}{c}\text { Tmax } \\
\text { trend }\end{array}$ & $\begin{array}{l}\text { Tmax } \\
p \text { value }\end{array}$ & Station & $\begin{array}{c}\text { Tmin } \\
\text { trend }\end{array}$ & $\begin{array}{c}\text { Tmin } \\
p \text { value }\end{array}$ \\
\hline Academy, SD & & 0.2082 & Academy, SD & - & 0.0021 \\
Algona, IA & - & 0.0022 & Algona, IA & 0.0701 \\
Bottineau, ND & & 0.9703 & Bottineau, ND & + & 0.0001 \\
Brookings, SD & - & 0.0001 & Brookings, SD & - & 0.0011 \\
Clark, SD & & 0.0630 & Clark, SD & + & 0.0001 \\
Crookston, MN & & 0.1007 & Crookston, MN & & 0.3414 \\
Graysville, MB & + & 0.0030 & Graysville, MB & + & 0.0192 \\
Medicine Hat, AB & - & 0.0400 & Medicine Hat, AB & & 0.0943 \\
Minot, ND & - & 0.0006 & Minot, ND & 0.0001 \\
Mitchell, SD & & 0.1156 & Mitchell, SD & 0.0823 \\
Morris, MN & - & 0.0017 & Morris, MN & \\
Muenster, SK & & 0.2377 & Muenster, SK & & 0.8194 \\
Poplar, MT & + & 0.0001 & Poplar, MT & + \\
Ranfurly, AB & & 0.1925 & Ranfurly, AB & + \\
Saskatoon, SK & + & 0.0008 & Saskatoon, SK & + & 0.0001 \\
Wahpeton, ND & & 0.6447 & Wahpeton, ND & + & 0.0001 \\
Watertown, SD & - & 0.0128 & Watertown, SD & & 0.0001 \\
Webster City, IA & - & 0.0001 & Webster City, IA & + & 0.0001 \\
\hline
\end{tabular}

The $(+)$ signifies a significant positive trend (warmer) and the $(-)$ signifies a significant negative trend (cooler). Stations in bold were statistically significant $(p<0.05)$ 


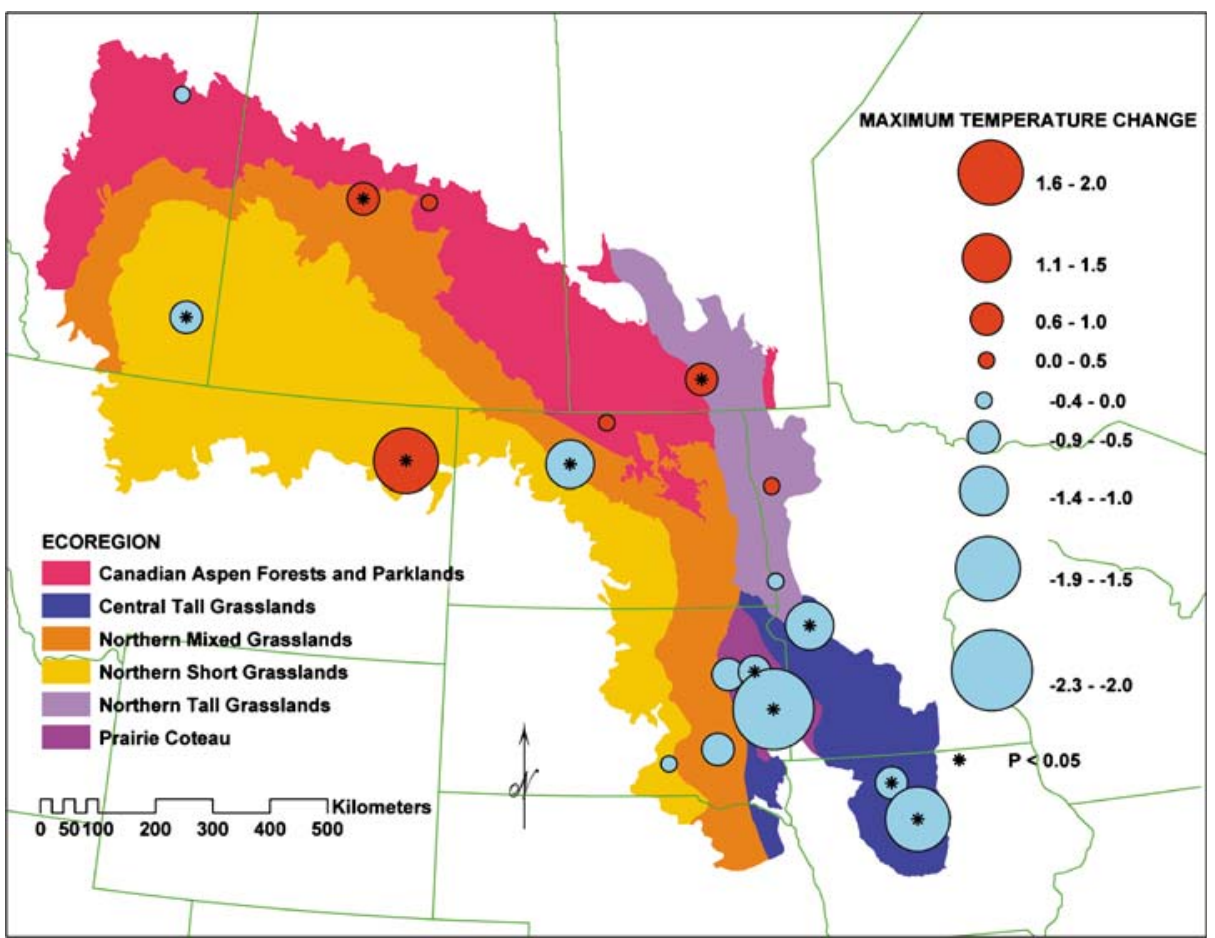

Fig. 6 Map of historic trends in maximum daily temperature for 18 weather stations and six ecoregions in the PPR

stations with significantly cooler minima were in the southeastern portion of the PPR and these exhibited only slight cooling $\left(<1^{\circ} \mathrm{C}\right)$.

\subsubsection{Seasonal temperature trends}

The temperature trends were not uniform seasonally. Although the same number (12 of 18) of stations experienced a significant rise in minimum temperatures in winter and summer, the magnitude of the warming was much greater in winter (Table 7). The average increase in minimum temperature was greater in winter than in summer, but the difference was not statistically significant [T test alpha $<0.05(p=0.1390)$ ].

For maximum temperatures more stations exhibited significant winter warming (7 of 18) than summer warming (5 of 18) (Table 8). In contrast, more stations exhibited significant summer cooling ( 8 of 18) than winter cooling (4 of 18) (Table 8). For the stations that exhibited significant warming, the magnitude of change was not statistically significant [T test alpha $<0.05(p=0.0917)]$.

\subsection{PDSI trends}

To represent the broad ecoregion patterns across the PPR, one weather station was selected from the central part of each ecoregion, and Box and Whisker plots were created to graphically show trends of central tendency and variability of decadal 


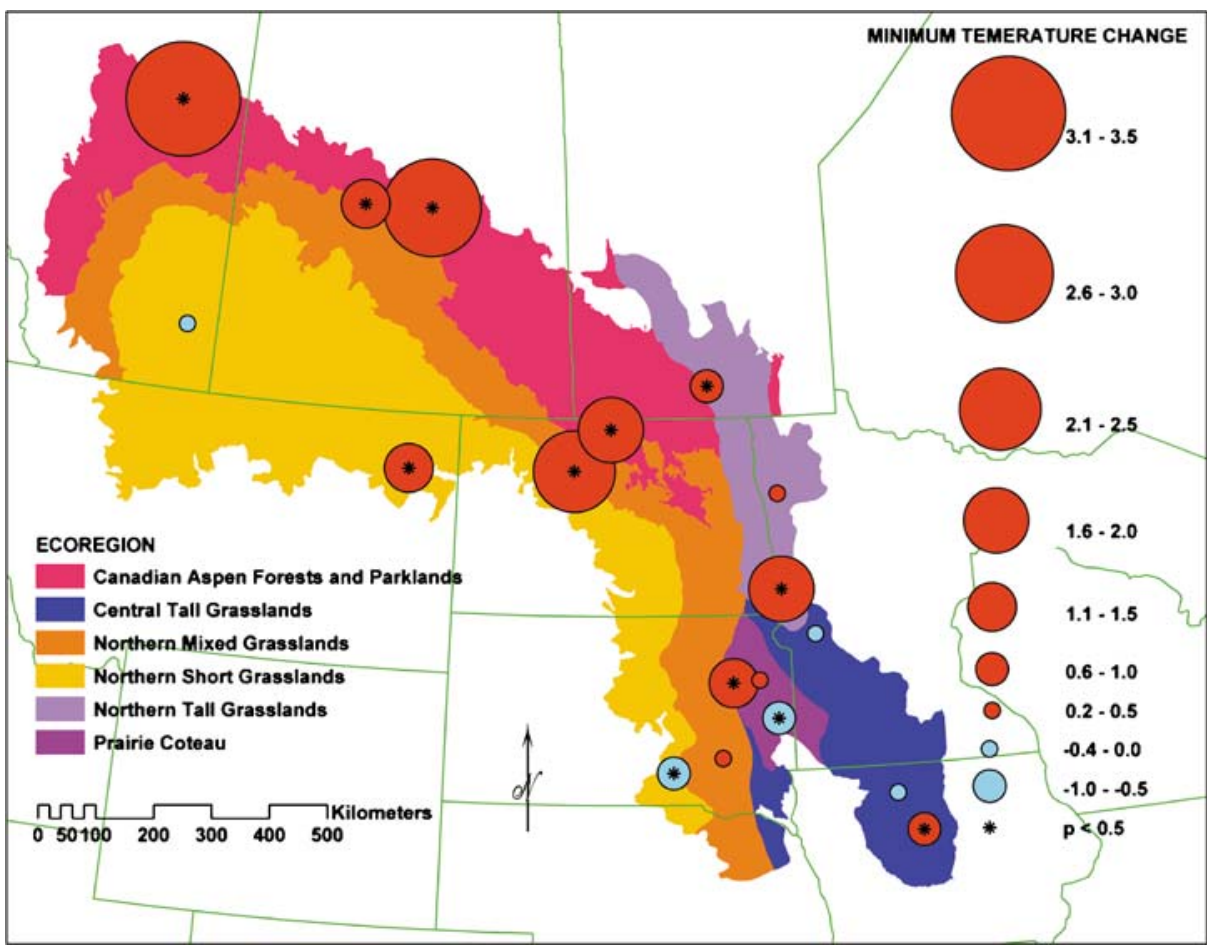

Fig. 7 Map of historic trends in minimum daily temperature for 18 weather stations and six ecoregions in the PPR

Table 7 Daily minimum temperature (TMIN) linear regression trends by season from 1906 to 2000 for 18 weather stations

\begin{tabular}{|c|c|c|c|c|c|}
\hline \multicolumn{3}{|l|}{ Tmin winter } & \multicolumn{3}{|l|}{ Tmin summer } \\
\hline Station & $p$ value & Trend $\left({ }^{\circ} \mathrm{C}\right)$ & Station & $p$ value & Trend $\left({ }^{\circ} \mathrm{C}\right)$ \\
\hline Academy, SD & 0.5703 & & Academy, SD & 0.0001 & -0.61 \\
\hline Algona, IA & 0.2012 & & Algona, IA & 0.0331 & -0.31 \\
\hline Bottineau, ND & 0.0000 & 2.40 & Bottineau, ND & 0.0000 & 1.25 \\
\hline Brookings, SD & 0.0007 & -1.04 & Brookings, SD & 0.0326 & -0.35 \\
\hline Clark, SD & 0.0001 & 1.24 & Clark, SD & 0.0000 & 1.96 \\
\hline Crookston, MN & 0.0019 & 1.00 & Crookston, MN & 0.1832 & \\
\hline Graysville, MB & 0.0190 & 0.78 & Graysville, MB & 0.0000 & 1.19 \\
\hline Medicine Hat, AB & 0.0363 & 0.79 & Medicine Hat, AB & 0.0000 & -0.82 \\
\hline Minot, ND & 0.0000 & 2.92 & Minot, ND & 0.0000 & 2.42 \\
\hline Mitchell, SD & 0.3106 & & Mitchell, SD & 0.0000 & 1.43 \\
\hline Morris, MN & 0.4645 & & Morris, MN & 0.0034 & 0.44 \\
\hline Muenster, SK & 0.0000 & 3.98 & Muenster, SK & 0.0000 & 2.23 \\
\hline Poplar, MT & 0.0000 & 3.59 & Poplar, MT & 0.1886 & \\
\hline Ranfurly, AB & 0.0000 & 4.3 & Ranfurly, AB & 0.0000 & 2.40 \\
\hline Saskatoon, SK & 0.0000 & 2.48 & Saskatoon, SK & 0.0000 & 0.57 \\
\hline Wahpeton, ND & 0.0000 & 1.98 & Wahpeton, ND & 0.0000 & 2.29 \\
\hline Watertown, SD & 0.0435 & 0.61 & Watertown, SD & 0.0000 & 0.90 \\
\hline Webster City, IA & 0.2531 & & Webster City, IA & 0.0000 & 1.00 \\
\hline
\end{tabular}

Stations in bold were statistically significant $(p<0.05)$ 
Table 8 Daily maximum temperature (TMAX) linear regression trends by season from 1906 to 2000 for 18 weather stations

\begin{tabular}{|c|c|c|c|c|c|}
\hline \multicolumn{3}{|l|}{ Tmax winter } & \multicolumn{3}{|l|}{ Tmax summer } \\
\hline Station & $p$ value & Trend $\left({ }^{\circ} \mathrm{C}\right)$ & Station & $p$ value & Trend $\left({ }^{\circ} \mathrm{C}\right)$ \\
\hline Academy, SD & 0.4570 & & Academy, SD & 0.1425 & \\
\hline Algona, IA & 0.0000 & -1.18 & Algona, IA & 0.0000 & -0.66 \\
\hline Bottineau, ND & 0.0000 & 1.05 & Bottineau, ND & 0.3438 & \\
\hline Brookings, SD & 0.0000 & -1.66 & Brookings, SD & 0.0000 & -2.02 \\
\hline Clark, SD & 0.7125 & & Clark, SD & 0.1892 & \\
\hline Crookston, MN & 0.0033 & 0.86 & Crookston, MN & 0.0093 & 0.44 \\
\hline Graysville, MB & 0.0005 & 1.10 & Graysville & 0.0000 & 0.90 \\
\hline Medicine Hat, AB & 0.0005 & 1.34 & Medicine Hat, AB & 0.0000 & -1.91 \\
\hline Minot, ND & 0.2298 & & Minot, ND & 0.0011 & -0.64 \\
\hline Mitchell, SD & 0.7213 & & Mitchell, SD & 0.1701 & \\
\hline Morris, MN & 0.0133 & -0.73 & Morris, MN & 0.0000 & -0.74 \\
\hline Muenster, SK & 0.0026 & 1.02 & Muenster, SK & 0.1136 & \\
\hline Poplar, MT & 0.0000 & 2.49 & Poplar & 0.0000 & 1.56 \\
\hline Ranfurly, AB & 0.1081 & & Ranfurly, AB & 0.0002 & -0.69 \\
\hline Saskatoon, SK & 0.0000 & 1.82 & Saskatoon, SK & 0.0132 & 0.47 \\
\hline Wahpeton, ND & 0.1722 & & Wahpeton, ND & 0.0002 & 0.63 \\
\hline Watertown, SD & 0.8129 & & Watertown, SD & 0.0136 & -0.44 \\
\hline Webster City, IA & 0.0000 & -1.50 & Webster City, IA & 0.0000 & -2.33 \\
\hline
\end{tabular}

Stations in bold were statistically significant $(p<0.05)$

PDSI values (Fig. 8). Decadal patterns showed considerable variability among PPR weather stations. For example, Medicine Hat, AB experienced near normal PDSI values during the 1930s but had consistently lower PDSI values during the 1920s and 1980s (Fig. 8). Similar results were found at other Canadian weather stations indicating that the northern portion of the PPR was more affected by the $1980 \mathrm{~s}$ drought than the 1930s drought. In contrast, the 1950s drought was more severe than that of the 1930s in the southeastern PPR (Iowa).

The PDSI value of -2.39 for the 1930 s was the driest decade for the PPR, based on a comparison of decadal averages for the 18 weather stations (Table 9). Drought during this decade also was the most widespread with 17 of the 18 weather stations with negative PDSI values. The lowest PDSI values occurred in the Dakotas and western Minnesota. Thirteen of 18 stations also had negative PDSI values in the 1920s.

Conversely the incomplete decade from 1906 to 1910 ranked as the wettest period, followed by the 1990s (Table 9) when 16 of the 18 weather stations had positive PDSI values. The next wettest decade was the 1970 s when 10 of 18 weather stations had positive values. The 1960 s represented a near "normal range" decade with a PDSI of 0.00 .

The 95-year PDSI trends across all eighteen stations indicated variable but mostly increasing moisture availability during the twentieth century in the eastern half of the PPR (Fig. 9). No stations in this region showed a significant decrease in moisture availability. The western half of the PPR exhibited a mix of trends; two stations had significantly wetter conditions (Medicine Hat, AB and Muenster, SK) and two developed significantly drier conditions (Ranfurly, AB and Saskatoon, SK). 

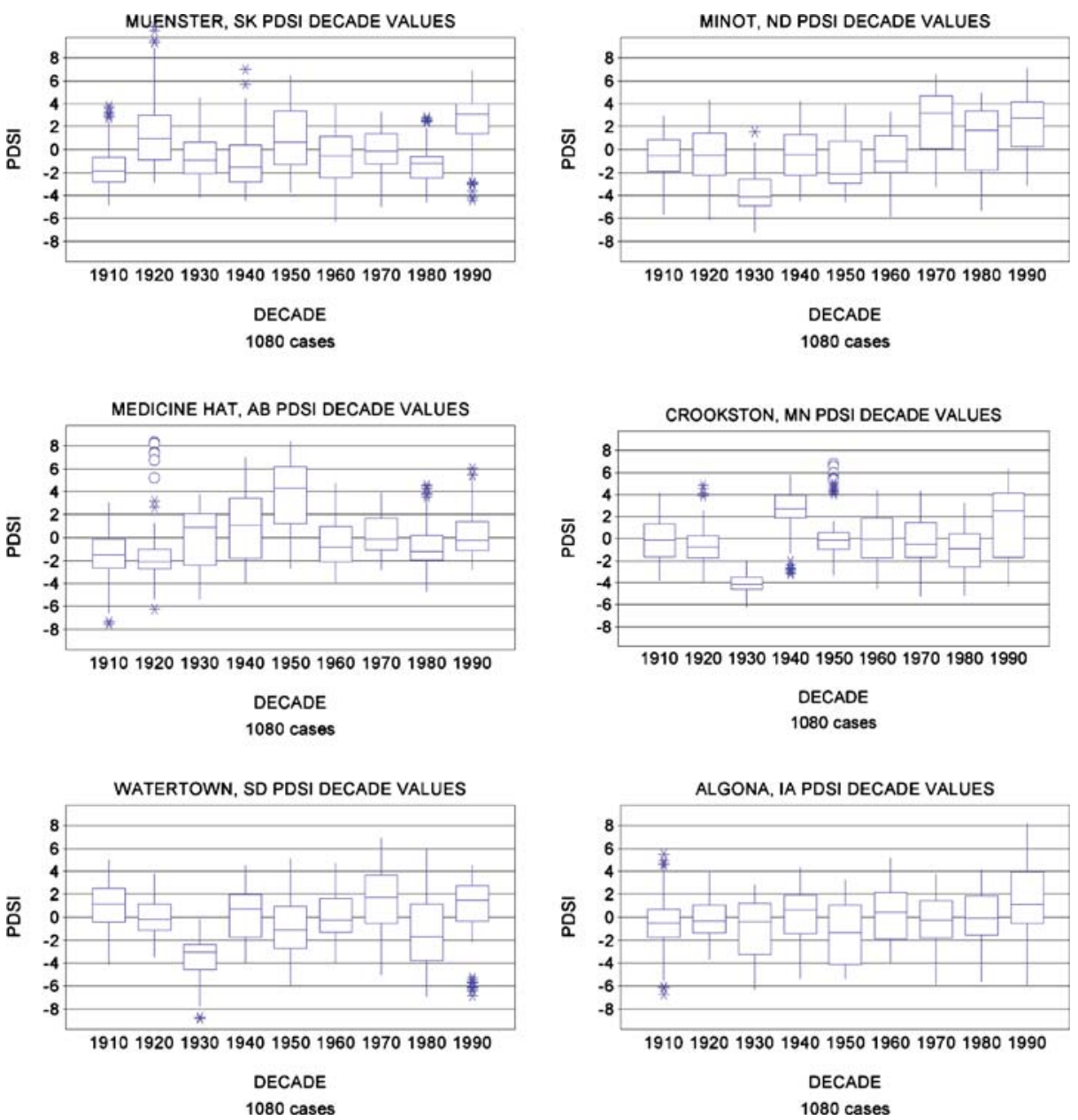

Fig. 8 Decadal PDSI box plots for six selected weather stations, one for each ecoregion. The box encloses the middle half of the data and the line that intersects the box is the median. The vertical lines at the top and the bottom of the box show the range (first and third quartile) of "typical" data values

\section{Discussion}

Strong temperature and precipitation gradients across the PPR combined to produce multiple climates varying in the degree of aridity. The west-east precipitation gradient was particularly steep, from about $300 \mathrm{~mm} /$ year to $900 \mathrm{~mm} /$ year. The north-south temperature gradient was more gradual, but the mean annual temperature of stations in the south averaged nearly $10^{\circ} \mathrm{C}$ warmer than those in the extreme north. The dryness expected from the much lower annual precipitation in the western Canadian prairies was moderated somewhat by the cooler temperatures and shorter growing season. In general, warmer sections received more precipitation than cooler regions. 
Table 9 Palmer Drought Severity Index (PDSI) averaged by decade for 18 Prairie Pothole Region weather stations and ranked from driest to wettest

\begin{tabular}{llc}
\hline PDSI & & \\
\hline Rank & Decade & Average \\
\hline 1 & 1930 & -2.39 \\
2 & 1920 & -0.33 \\
3 & 1980 & -0.32 \\
4 & 1950 & -0.14 \\
5 & 1910 & -0.10 \\
6 & 1960 & 0.00 \\
7 & 1940 & 0.15 \\
8 & 1970 & 0.47 \\
9 & 1990 & 1.28 \\
10 & 1900 & 1.97 \\
\hline
\end{tabular}

The twentieth century climate of the PPR was punctuated by significant droughts. These conditions have occurred over small and large areas and lasted as short as several growing seasons or as long as a decade (Skaggs 1975; Laird and Cumming 1998; Nkemdirim and Weber 1999). Most PPR stations recorded their lowest PDSIs during the 1930s, however geographically restricted droughts also were severe.

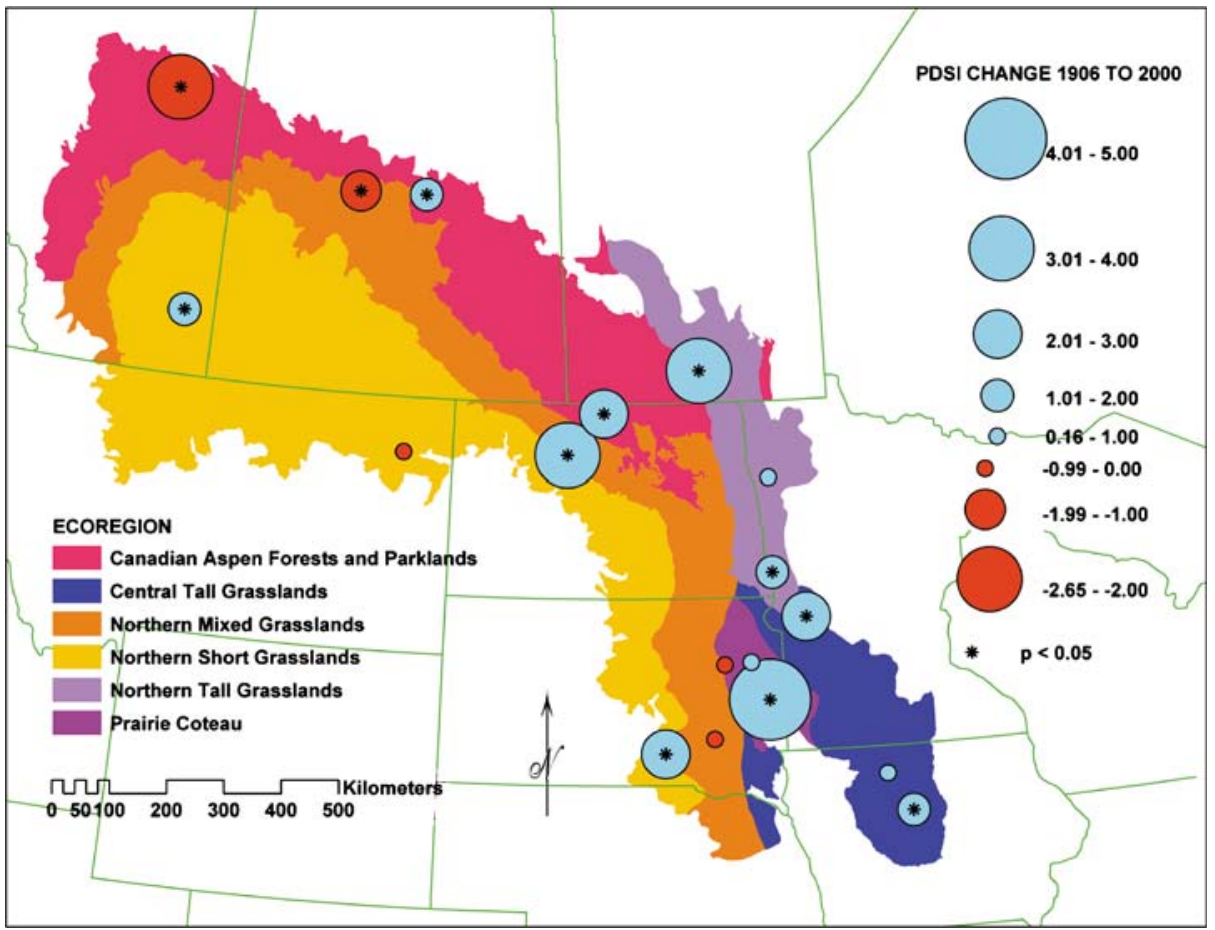

Fig. 9 Prairie Pothole Region PDSI trends from 1906 to 2000 based on simple linear regression. Circle size indicates the magnitude of change. Red circles represent negative slope or stations with decreasing PDSI values. Blue circles represent stations with increasing PDSI values 
Nkemdirim and Weber (1999) found that the 1980s drought in the southern Canadian prairies was comparable in intensity to the 1930s drought with PDSI values of -1.33 and -1.39 , respectively.

The PPR generally became warmer and wetter during the twentieth century. Our results showed that average daily air temperature rose by about $1.0^{\circ} \mathrm{C} / 95$ years, slightly above the global average of $0.6^{\circ} \mathrm{C}\left( \pm 0.2^{\circ} \mathrm{C}\right)$ since the late-nineteenth century, and about $0.4^{\circ} \mathrm{F}\left(0.2\right.$ to $\left.0.3^{\circ} \mathrm{C}\right)$ over the past 25 years (National Oceanic and Atmospheric Administration 2006). Similarly, Gullett and Skinner (1992) found that Canada had warmed by $1.1^{\circ} \mathrm{C}$ between 1895 and 1991 . Nearly all of this increase was caused by higher daily minimum rather than daily maximum temperatures, except for some northern and western stations. Karl et al. (1993) found that these asymmetric trends also occurred globally. They reported the minimum temperature increased at a rate three times that of the maximum temperature during the period 1951-1990 $\left(0.84^{\circ} \mathrm{C}\right.$ versus $\left.0.28^{\circ} \mathrm{C}\right)$. Both maximum and minimum temperatures have increased more at higher latitudes, but minimum temperatures more so (Karl et al. 1993; Easterling et al. 1997). The National Assessment Synthesis Team (2001) reported a $1.0^{\circ} \mathrm{C}$ increase in mean surface temperature for the northern and central Great Plains of the United States during the twentieth century. Larger increases in temperature of up to $3^{\circ} \mathrm{C}$ have been reported for parts of Montana and the Dakotas (National Assessment Synthesis Team 2000).

Temperature also has changed seasonally. Winters have been getting particularly warmer across North America. Bonsal et al. (2001) found fewer days in Canada with extreme low temperatures during winter, spring, and summer, and more days with extreme high temperatures during winter and spring. A shorter ice season has been caused by later freezing and earlier breakup on Northern Hemisphere lakes and rivers. Magnuson et al. (2000) using records derived from human observations in eastern North America showed that lakes and rivers were freezing at later dates and breaking-up on earlier dates in 38 of 39 records from 1846 to 1995. Model simulations have projected that the biggest reduction in the number of frost days (20 fewer days per year) will occur from the Great Plains westward by 2080-2099 (Meehl et al. 2004).

Our analysis determined that precipitation averaged across the PPR increased during the past century, despite a precipitation decrease in the western Canadian prairies. Because a large portion of the U.S. weather stations used in our analysis were extremely wet in the 1990s, the last decade in our data set, the regression analysis conducted could have overestimated precipitation increases during the twentieth century. Garbrecht and Rossel (2002) also found that the northern and northwestern Great Plains experienced a precipitation increase near the end of a 105-year record, but it was primarily confined to the final decade of the twentieth century. They stated, "fewer dry years over the last 10 years, as opposed to an increase in very wet years, were the leading cause of the observed wet conditions." Changnon (2001) showed that between 1950 and 1994 thunderstorms have not only been more frequent, but also have produced more rainfall in the Midwest and Great Plains. Over the last 100 years, however, annual precipitation has decreased by $10 \%$ in eastern Montana and in North Dakota (National Assessment Synthesis Team 2001). In the eastern Great Plains, precipitation has increased by more than 10\% (National Assessment Synthesis Team 2001). Sauchyn et al. (2003) stated that droughts in northernmost Montana and Alberta in the twentieth century were more 
frequent but shorter in duration than droughts in the eighteenth and nineteenth centuries derived from proxy data.

Wetlands respond to the strong spatial and temporal change in climatic conditions across the PPR. Wetlands in the midsection of the PPR (eastern Dakotas and southeastern Saskatchewan) experienced the most dynamic climate during the twentieth century, and as a result, they may be on average the most productive because they pass through all stages of the vegetation cover cycle more rapidly and more frequently (Murkin et al. 1997; Haig et al. 1998; Johnson et al. 2005). For example, high water produces a lake phase with little emergent vegetation and few nutrients in bottom detritus, while chronic low water produces the dry marsh phase with heavy emergent vegetation and high nutrient sequestering in plant material. The occurrence of both extremes during a weather cycle and intermediate stages (regenerating and degenerating marsh phases) creates plant population turnover (maintaining biological diversity) and nutrient mobilization (van der Valk and Davis 1978; Johnson et al. 2004). The central section of the PPR historically had faster cover cycle return times (Johnson et al. 2005); however, the wetter fringes historically have provided refugia from droughts. Wetlands occupying the northern and eastern fringes of the PPR (northern Saskatchewan, Minnesota, Iowa), where climate has historically been wetter, have more stable water levels but on average are probably less productive. In contrast, wetlands along the western fringes of the PPR (Montana, Alberta) more often experience prolonged periods of dry or low water conditions.

The eastern portion of the PPR has experienced the most wetland drainage for agriculture. From the 1870 s to the 1930 s, nearly all the prairie wetlands in Iowa, southwestern Minnesota, and the Red River Valley were drained (Schrader 1955; Dahl and Allord 1996). Iowa lost $89 \%$ of its prairie wetlands during the twentieth century (Dahl 1990). Minnesota lost more than $90 \%$ of its western prairie wetlands (Anderson and Craig 1984). Wetland losses were 49\% in North Dakota, 35\% in South Dakota, and 27\% in Montana (Dahl 1990).

Current wetland densities are a function of geological history and the rate of drainage for agriculture across ecoregions; the tall grass ecoregion has 3 to 4 wetlands per square kilometer while ecoregions farther west (mixed and short grassland) have upwards of 15 wetlands per square kilometer (Table 10). Drainage of wetlands in the wetter, eastern PPR has lowered the potential of the PPR to produce waterfowl in a warmer greenhouse climate. Model simulations have shown that changes in climate of the magnitude predicted by global circulation models could shift climatic conditions favorable for wetland inundation eastward toward areas where most

Table 10 Wetland density based on the number of wetlands per square kilometer for Prairie Pothole Region ecoregions of the United States

\begin{tabular}{lc}
\hline Ecoregion & Wetlands $/ \mathrm{km}^{2}$ \\
\hline Canadian aspen forests and parklands & 15.5 \\
Central tall grasslands & 3.6 \\
Northern mixed grasslands & 15.5 \\
Northern short grasslands & 11.0 \\
Northern tall grasslands & 4.2 \\
Prairie coteau & 7.8 \\
\hline
\end{tabular}

Densities calculated from National Wetlands Inventory data (Guntenspergen, unpublished data) 
wetlands have been drained for agriculture (Johnson et al. 2005) (Table 10). Climate change poses a conservation challenge because the highest densities of intact wetland basins and best upland nesting cover (Weller 1994; Reynolds et al. 2001) occur in the drier PPR where the effects of climate change are projected to be the most severe (USGS 2006). Restoration of drained wetlands in the east, albeit an expensive prospect (Interagency Workgroup on Wetland Restoration 2003), could help diminish the effects of increased droughts in the climatically drier west.

Scientists have yet to work out how waterfowl populations may be affected by likely changes in inter-annual variability and within-year distribution of precipitation. Uncertainty about the future periodicity in extreme events such as flooding and drought leads to even more uncertainty on the impacts to waterfowl. Future within-year distribution of precipitation will likely affect wetland dynamics such as cover cycles and return times but the degree to which these changes will influence waterfowl populations remains unclear.

While waterfowl have adapted to the historically high spatial and temporal variability of water and plant cover in the PPR (Hansen and McKnight 1964; Crissey 1969; Bethke and Nudds 1993), fewer options may exist in the future under the drier scenarios expected. Sorenson et al. (1998) estimated that duck populations breeding in the PPR could decrease by half under most climate scenarios.

Our results show that the climate during the twentieth century did not change uniformly across the PPR. In particular the climate of the Canadian Apsen Forests an Parklands warmed considerably more than the global mean during the twentieth century. The Central Tall Grasslands generally cooled rather than tracking the global trend of warming during the twentieth century. Model simulations (Johnson et al. 2005) indicate that an additional temperature change of this magnitude in the future without increased precipitation would strongly reduce the contribution of the western PPR to overall wetland-associated biodiversity. Conversely, the eastern and historically the wettest portion of the PPR, has become even wetter. Thus, the general trend of the climatic gradient from west to east steepened during the twentieth century periodically reducing the functional area of the PPR. Wetlands in the east have become less productive because they are too wet (fewer complete cover cycles per century) while wetlands in the west have become less productive because they dry out more frequently.

We do not know whether the trends in climate recorded during the twentieth century for the PPR will continue into the future. Predictions vary quite widely among General Circulation Models (GCMs) for precipitation but more narrowly for temperature (IPCC 2007). If climate trends from the twentieth century do continue, the steeper west to east gradient in wetness may further shrink the productive portion of the PPR. The consequences for wetlands and waterfowl could be substantial. Should the eastern PPR begin to warm, a more productive wetland climate would result; however, a significant portion of the previously drained wetlands would have to be restored to offset less productive conditions in the western PPR. The climate should be watched closely in the future to look for signs of higher evaporative demand and to prepare for a PPR with less productive wetlands and fewer waterfowl. Only three long-term monitoring sites for wetland hydrology and vegetation are available to assist in detecting future trends (Johnson et al. 2004). Expansion of this network would greatly improve our ability to forecast and plan for climate change in the PPR. 
Acknowledgments This work was funded by the U.S. Geological Survey, Biological Resources Division (BRD) Climate Change Program and by the U.S. Environmental Protection Agency (EPA), Science to Achieve Results (STAR) program, managed by the EPA's Office of Research and Development (ORD), National Center for Environmental Research (NCER). STAR research supports the agency's mission to safeguard human health and the environment. Twentieth century weather data were obtained from the National Climate Data Center (NCDC), National Oceanic and Atmospheric Administration (NOAA), U.S. Department of Commerce and Environment Canada (EC) Manitoba and Arctic.

\section{References}

Ahrens CD (2007) Meteorology today: an introduction to weather, climate, and the environment, 8th edn. Thompson, Brooks/Cole

Alley WM (1984) The Palmer Drought Severity Index: limitations and assumptions. J Clim Appl Meteor 23(7):1100-1109. doi:10.1175/1520-0450(1984)023<1100:TPDSIL >2.0.CO;2

Anderson RC (1983) The eastern prairie-forest transition: an overview. In: Brewer R (ed) Proceedings, 8th North American prairie conference, Western Michigan University, Department of Biology, Kalamazoo, Michigan, 1-4 August 1982, pp 86-92

Anderson JP, Craig WJ (1984) Growing energy crops on Minnesota's wetlands: the land use perspective. University of Minnesota Center for Urban and Regional Affairs, Publication CURA 84-3.95

Bartlein PJ, Webb T III, Fleri E (1984) Holocene climatic changes estimated from pollen data from the northern Midwest. Quat Res 22:361-347. doi:10.1016/0033-5894(84)90029-2

Bartlein PJ, Anderson KH, Anderson PM, Edwards ME, Mack CJ, Thompson RS, Webb RS, Webb T III, Whitlock C (1998) Paleocene simulations for North America of the past 21,000 years; features of the simulated climate and comparisons with paleoenvironmental data. Quat Sci Rev 17(6-7):549-585. doi:10.1016/S0277-3791(98)00012-2

Batt BDJ, Anderson MG, Anderson CD, Caswell FD (1989) The use of prairie potholes by North American ducks. In: van der Valk A (ed) Northern Prairie Wetlands. Iowa State University Press, Ames, pp 204-227

Bethke RW, Nudds TD (1993) Variation in the diversity of ducks along a gradient of environmental variability. Oecologia 93(2):242-250. doi:10.1007/BF00317677

Bird RD (1961) Ecology of the aspen parkland of western Canada in relation to land use. Canada Department of Agriculture, Research Branch, Publication 1066, Ottawa, ON

Bluemle JP, Sabel JM, Wibjorn K (1999) Rate and magnitude of past global climate changes. Environ Geosci 6(2):63-75

Bonsal BR, Zhang X, Vincent LA, Hogg WD (2001) Characteristics of daily and extreme temperatures over Canada. J Climate 14(9):1959-1976. doi:10.1175/1520-0442(2001)014<1959: CODAET $>2.0 . \mathrm{CO} ; 2$

Borchert JA (1950) The climate of the North American grassland. Ann Assoc Am Geogr 40(1):1-39

Bryson RA, Hare FK (eds) (1974) World survey of climatology. Climates of North America, vol 11. Elsevier, New York, p 420

Buell MF, Facey V (1960) Forest-prairie transition west of Itasca Park, Minnesota. B. Torrey Bot Club 87(1):46-58

Changnon SA (2001) Thunderstorm rainfall in the conterminous United States. B Am Meteorol Soc 82(9):1925-1940. doi:10.1175/1520-0477(2001)082<1925:TRITCU >2.3.CO;2

Clark MP, Hay LE (2004) Use of medium-range numerical weather prediction model to produce forecasts of streamflow. J Hydrometeor 5(1):15-32

Clark JS, Grimm EC, Lynch J, Mueller PG (2001) Effects of Holocene climate change on the C4 grassland/woodland boundary in the Northern Plains, USA. Ecology 82(3):620-636. doi:10. 1890/0012-9658(2001)082[0620:EOHCCO]2.0.CO;2

Cook ER, Meko DM, Stahle DW, Cleaveland MK (1999) Drought reconstructions for the continental United States. J Climate 12(4):1145-1162. doi:10.1175/1520-0442(1999)012<1145:DRFTCU> 2.0.CO;2

Crissey WF (1969) Prairie potholes from a continental viewpoint. In Saskatoon wetlands seminar. Can Wildl Serv Rept 6:161-171

Dahl TE (1990) Wetlands losses in the United States 1780's to 1980's. U.S. Department of the Interior, Fish and Wildlife Service, p 13 
Dahl TE, Allord GJ (1996) Technical aspects of wetlands. History of wetlands in the conterminous United States. National Water Summary: Wetland Resources. US Geological Survey WaterSupply Paper 2425

DeGaetano AT, Eggleston KL, Knapp WW (1995) A method to estimate missing daily maximum and minimum temperature observations. J Appl Meteorol 34(2):371-380. doi:10.1175/15200450(1995)034<0371:AMTEMD>2.0.CO;2

Denton GH, Porter SC (1970) Neoglaciation. Sci Am 222:101-110

Easterling DR, Horton B, Jones PD, Peterson TC, Karl TR, Parker DE, Salinger MJ, Razuvayev V, Plummer N, Jamason P, Folland CK (1997) Maximum and minimum temperature trends for the globe. Science 277(5324):364-367. doi:10.1126/science.277.5324.364

Eischeid JK, Pasteris PA, Diaz HF, Plantico MS, Lott NJ (2000) Creating a serially complete, national daily time series of temperature and precipitation for the western United States. J Appl Meteor 39(9):1580-1591. doi:10.1175/1520-0450(2000)039<1580:CASCND>2.0.CO;2

Garbrecht JD, Rossel FE (2002) Decade-scale precipitation increase in Great Plains at the end of 20th Century. J Hydrol Eng 7(1):64-75

Gullett DW, Skinner WR (1992) The state of Canada's climate: temperature change in Canada 18951991. A state of the environment report $92-2$

Haig SM, Mehlman DW, Oring LW (1998) Avian movements and wetland connectivity in landscape conservation. Conserv Biol 12(4):749-758

Hansen HA, McKnight DE (1964) Emigration of drought-displaced ducks to the Arctic. Trans N Am Wildl Nat Resour Conf 29:119-127

Hansen JE, Sato M, Glascoe J, Ruedy R (1998) A common-sense climate index: is climate changing noticeably? Proc Natl Acad Sci 95(8):4113-4120

Hayes MJ, Svoboda MD, Waltman WJ, Goddard S, Hubbard KG (2002) Monitoring droughts with improved drought index resolution. Paper presented at session 8.2 in 13th conference on applied meteorology, 13-16 May 2002

Interagency Workgroup on Wetland Restoration (2003) An introduction and user's guide to wetland restoration, creation, and enhancement. Environmental Protection Agency, Office of Water, Washington DC. Available online. http://www.nmfs.noaa.gov/habitat/habitatconservation/ publications/introfinal.pdf. Cited 31 May 2007

Intergovernmental Panel on Climate Change (IPCC) (2007) Climate change 2007: the physical science basis, working group I contribution to the fourth assessment report of the IPCC. Available online. http://ipcc-wg1.ucar.edu/wg1/wg1-report.html. Cited 30 May 2007

Johnson WC, Boettcher SE, Poiani KA, Guntenspergen GR (2004) Influences of weather extremes on the hydrology of glaciated prairie wetlands. Wetlands 24(2):385-398

Johnson WC, Millett BV, Gilmanov T, Voldseth RA, Guntenspergen GR, Naugle DE (2005) Vulnerability of northern prairie wetlands to climate change. BioScience 55(10):863-872

Karl TR, Williams CN Jr (1987) An approach to adjusting climatological time series for discontinuous inhomogeneities. J Appl Meteorol 26(12):1744-1763. doi:10.1175/1520-0450(1987)026< 1744:AATACT>2.0.CO;2

Karl TR, Jones PD, Knight RW, Kukla G, Plummer N, Razuvayev V, Gallo KP, Lindseay J, Charlson RJ, Peterson TC (1993) A new perspective on recent global warming: asymmetric trends of daily maximum and minimum temperature. B Am Meteorol Soc 74(6):1007-1023. doi:10.1175/15200477(1993)074<1007:ANPORG >2.0.CO;2

Karl TR, Knight RW, Easterling, ER, Quayle RG (1995) Trends in U.S. climate during the twentieth century. Consequences 1(1). Available online http://www.gcrio.org/CONSEQUENCES/ spring95/Climate.html

Kemp WP, Burnell DG, Everson DO, Thomson AJ (1983) Estimating missing daily maximum and minimum temperatures. J Climate Appl Meteor 22(9):1587-1593. doi:10.1175/15200450(1983)022<1587:EMDMAM>2.0.CO;2

Laird KR, Cumming BF (1998) Tracing droughts into the past: two millennia of North American drought events recorded in lake-bottom cores. Science Spectra 11:50-57

Larson D (1995) Effects of climate on numbers of northern prairie wetlands. Clim Change 30(2):169180. doi:10.1007/BF01091840

Lemmen DS, Beaudoin AB, Vance RE (1997) Paleoenvironmental records of postglacial climate change in the prairie ecozone. In: The ecological monitoring and assessment network report on the third national science meeting, Saskatoon, Saskatchewan, Ecological Monitoring Coordinating Office, Canada Centre for Inland Waters, Burlington, Ontario 21-25 January 1997. http://www.eman-rese.ca/eman/reports/publications/nm97_paleo/intro.html. Cited 10 Jan 2003 
Lohani VK, Loganathan GV (1997) An early warning system for drought management using the Palmer Drought Index. J Am Water Resour As 33(6):1375-1386

Magnuson JJ, Robertson DM, Benson BJ, Wynne RH, Livingstone DM, Arai T, Assel RA, Barry RG, Card V, Kuusisto E, Granin NG, Prowse TD, Stewart KM, Vuglinski VS (2000) Historical trends in lake and river ice cover in the Northern Hemisphere. Science 289:1743-1746

Meehl GA, Tebaldi C, Nychka D (2004) Changes in frost days in simulations of Twenty-first century climate. Clim Dynam 23(5):495-511

Millett BV (2004) Vulnerability of northern prairie wetlands to climate change. Dissertation, South Dakota State University

Mott P, Sammis TW, Southward GM (1994) Climate data estimation using climate information from surrounding climate stations. Appl Eng Agric 10:41-44

Murkin HR, Murkin EJ, Ball JP (1997) Avian habitat selection and prairie wetland dynamics: a 10-year experiment. Ecol Appl 7(4):1144-1159

National Agricultural Decision Support System (NADSS) (2003) University of Nebraska-Lincoln Department of Computer Science and Engineering, the University of Nebraska Board of Regents and the USDA Risk Management Agency. Software download available at http://nadss.unl.edu. Cited 13 Feb 2003

National Assessment Synthesis Team (2000) Climate change impacts on the United States: the potential consequences of climate variability and change-overview. Great Plains. Cambridge University Press, New York

National Assessment Synthesis Team (2001) Climate change impacts on the United States: the potential consequences of climate variability and change-foundation. Cambridge University Press, New York

National Climatic Data Center (NCDC) (2008) Climate of 2007 Annual Report. Available online. http://www.ncdc.noaa.gov/oa/climate/research/2007/ann/global.html. Cited 16 Jun 2008

National Oceanic and Atmospheric Administration (2006) Global warming: frequently asked questions. http://www.ncdc.noaa.gov/oa/climate/globalwarming.html. Cited 23 May 2006

Nkemdirim L, Weber L (1999) Comparison between the droughts of the 1930s and the 1980s in the southern prairies of Canada. J Climate 12:2434-2450. doi:10.1175/1520-0442(1999)012<2434: CBTDOT $>.0 . \mathrm{CO} ; 2$

Omernik JM (1987) Ecoregions of the conterminous United States. Ann Assoc Am Geogr 77(1): $118-125$

Omernik JM (1995) Ecoregions: a framework for environmental management. In: Davis W, Simon T (eds) Biological assessment and criteria: tools for water resource planning and decision making. Lewis, Chelsea

Poiani KA, Johnson WC (1991) Global warming and prairie wetlands: potential consequences for waterfowl habitat. BioScience 41(9):611-618

Reynolds RE, Shaffer TL, Renner RW, Newton WE, Batt BDJ (2001) Impact of the Conservation Reserve Program on duck recruitment in the U.S. prairie pothole region. J Wildl Manage 65(4):765-780. Available online. http://www.npwrc.usgs.gov/resource/birds/duckrecr/index.htm. Cited 30 May 2007

Riebsame WE, Changnon SA Jr, Karl TR (1991) Drought and natural resources management in the United States: impacts and implications of the 1987-89 drought. Westview, Boulder, p 174

Sauchyn DJ, Stroich J, Beriault A (2003) A paleoclimatic context for the drought of 1999-2001 in the northern Great Plains of North America. Geog J 169(2):158-167

Schrader TA (1955) Waterfowl and the potholes of the north central states. In: The yearbook of agriculture 1955. Washington DC, US Department of Agriculture, 84th Congress, 1st Session, House Document no. 32:596-604

Shapley MD, Johnson WC, Engstrom DR,Osterkamp WR (2005) Late-Holocene flooding and drought in the Northern Great Plains, USA, reconstructed from tree rings, lake sediments, and ancient shorelines. Holocene 15(1):29-41

Skaggs RH (1975) Drought in the United States, 1931-40. Ann Assoc Am Geogr 65(3):391-402

Sorenson LG, Goldberg R, Root TL, Anderson MG (1998) Potential effects of global warming on waterfowl populations breeding in the northern Great Plains. Clim Change 40(2-3):343-369. doi:10.1023/A:1005441608819

Thornthwaite CW, Mather JR (1957) Instructions and tables for computing potential evapotranspiration and the water balance. Publ Climatol 10:185-311

Tiner RW (2003) Geographically isolated wetlands of the United States. Wetlands 23(3):494-516

U.S. Environmental Protection Agency (USEPA) (1996) Level III ecoregions of the continental United States (revision of Omernik, 1987). Corvallis, Oregon, U.S. Environmental Protection 
Agency—National Health and Environmental Effects Research Laboratory Map M-1, various scales

U.S. Geological Survey (USGS) (2006) Prairie wetlands and climate change—droughts and ducks on the Prairies USGS FS 2006-3144 Available online. http://www.pwrc.usgs.gov/products/ factsheets/Climate\%20Change\%20FSsm.pdf. Cited 30 May 2007

van der Valk AG (ed) (1989) Northern Prairie wetlands. Iowa State University Press, Ames, p 400

van der Valk AG, Davis CB (1978) The role of the seed bank in the vegetation dynamics of prairie glacial marshes. Ecology 59:322-335

Weller MW (1994) Freshwater marshes: ecology and wildlife management, 3rd edn. University of Minnesota, Minneapolis

Wells PV (1970) Postglacial vegetational history of the Great Plains. Science 167:1574-1582

Wiken EB (1986) Terrestrial ecozones of Canada, ecological land classification, Series No. 19. Environment Canada, Hull Quebec, p 26, and map

Winter TC (1989) Hydrologic studies of wetlands in the northern prairie. In: van der Valk A (ed) Northern Prairie wetlands. Iowa State University Press, Ames, pp 16-54

Winter TC, LaBaugh JW (2003) Hydrologic considerations in defining isolated wetlands. Wetlands 23(3):532-540

Winter TC, Rosenberry DO (1998) Hydrology of prairie pothole wetlands during drought and deluge: a 17-year study of the Cottonwood Lake wetland complex in North Dakota in the perspective of longer term measured and proxy hydrologic records. Clim Change 40:189-209. doi:10.1023/A:1005448416571

Woodhouse CA, Overpeck JT (1998) 2000 years of drought variability in the central United States. B Am Meteorol Soc 79(12):2693-2714. doi:10.1175/1520-0477(1998)079<2693:YODVIT>2.0.CO;2 